\title{
THE OPERATION OF FINANCIAL RESPONSIBILITY LAWS
}

\author{
N. P. FeinstngeR*
}

Since I925 twenty-seven states, ${ }^{1}$ the District of Columbia, Hawaii and eight Canadian provinces" have enacted certain statutes generically termed "financial responsibility laws,"3 designed to protect and indemnify the public against damage caused in the operation of automobiles." The obligation of these laws, conditioned on the happening of an automobile accident and a finding of fault, consists of payment of damages caused in an accident, ${ }^{5}$ or furnishing of proof of ability to pay damages in future accidents, or both.

The pattern for such laws is a bill drafted by the American Automobile Association in 1928 and revised in 1930 , I932, and $1935 .^{\circ}$ Among the chief proponents for enactment have been various automobile and insurance organizations. The coincidence of demands for the enactment of compulsory insurance acts like the Massa-

- A.B., r926, J.D., 1928, University of Michigan. Member of the New York and Wisconsin Bars. Associate Professor, University of Wisconsin Law School. Author of Financial Responsibility Laws and Compulsory Insurance: The Problem in Wisconsin (1935) 10 Wisconsin Law Review, 192, and other contributions to legal periodicals.

${ }^{1}$ Arizona, California, Colorado, Connecticut, Delaware, Indiana, Iowa, Kentucky, Maine, Maryland, Michigan, Minnesota, Nebraska, New Hampshire, New Jersey, New York, North Carolina, North Dakota, Ohio, Oregon, Pennsylvania, Rhode Island, South Dakota, Vermont, Virginia, West Virginia and Wisconsin. The Connecticut law, enacted in 1925 and effective January $I, 1926$, is the oldest. Conn. Pub. Acts 1925, c. I83. In addition to the foregoing states; Massachusetts has such a law, supplementary to its compulsory liability insurance act, operative only with respect to the non-payment of property damage judgments.

2 Alberta, British Columbia, Manitoba, New Brunswick, Nova Scotia, Ontario, Prince Edward Island and Saskatchewan. Conditions did not permit of a study of the Canadian or Hawaiian laws in detail.

"Sometimes described as "safety responsibility," "automobile liability security" or "model" acts.

"This study is concerned primarily with compensation for personal injuries, the chief subject of controversy, and deals mainly with private passenger automobiles. Public or commercial cars involve somewhat different problems and receive or invite special legislative treatment. See Brownfield, Compulsory Liability Insurance for Commercial Motor Vehicles, infra, p. 571, It appears that between $75 \%$ and $90 \%$ of all motor vehicles involved in accidents are private passenger automobiles.

"This requirement is frequently embodied in a separate statute and is widely known as the "damage judgment law."

${ }^{8}$ This bill in substance was adopted in 1934 by the National Conference on Street and Highway Safety as Act IV of the Uniform Vehicle Code, and is designated therein as the Uniform Motor Vehicle Safety-Responsibility Act. Both the A. A. A. bill and the Uniform Act are termed "Model Bills." A third type of act, also substantially the same, is the Uniform Automobile Liability Security Act, sponsored by the Uniform State Law Commissioners after considering a compulsory insurance law. See Commissioner's Prefatory Note, 9 UN. L. ANN. (1935) 15-16. 
chusetts law, ${ }^{7}$ opposed by such organizations, with the rapid spread of financial responsibility statutes, suggests that the latter were enacted as compromise or substitute measures. ${ }^{8}$ Indeed many of the arguments in their support are in essence arguments against compulsory insurance. It is the purpose of this study to examine the theory and administration of such laws in the light of their declared object, namely, increased public protection, pecuniary and otherwise, in respect to motor vehicle operation.

\section{Outline of Procedure Followed in this Study}

Questionnaires and letters were sent to the motor vehicle administrators in all jurisdictions concerned. The response showed a most commendable desire to coöperate ${ }^{\mathfrak{a}}$ but did not provide very adequate statistical information. The most complete statistics were furnished by Connecticut, Maine, New Jersey, New York, Pennsylvania, and Vermont. In many states various aspects of motor vehicle control are handled by different departments. In most, statistics have only recently begun to be kept. In all states the law has been so recently enacted or amended that even the most complete and orderly records would be inconclusive. Finally, the questionnaire itself proved in some respects inadequate to bring about the information most needed to present a rounded picture. It was surprising therefore to find so many administrators ready to state definite opinions of the law in its present form and operation. ${ }^{10}$ Nevertheless the returns taken as a whole do indicate certain trends and provide a basis for some observations and conclusions.

In addition to statistical material and opinions of administrators, it was sought to ascertain whether and how the various state bar associations had considered the general problem..$^{11}$ Finally, articles ${ }^{12}$ and decisions ${ }^{13}$ on the subject were reviewed.

\footnotetext{
${ }^{7}$ Mass. Acts 1925 , c. 346 , as amended, effective Jan. I, I927.
}

${ }^{s}$ See, for example, an address by R. Leighton Foster, K. C., Superintendent of Insurance for the Province of Ontaria, Canada, delivered before the National Convention of Insurance Commissioners at Scattle, Wash., on July ro $_{1}$ 1935. At page 7 of the printed report of his speech, Mr. Foster remarks: "I should like to say, however, in this connection, that the Canadian provincial Motor Vehicle and Insurance Commissioncrs feel they owe a great debt of gratitude to the Safety Responsibility Committee of the American Automobile Association for the law drafted and recommended by it which they have so generally adopted and that they are satisfied it has represented a staunch bulwark against the enactment of general compulsory insurance legislation of the character in force in Massachusetts by scveral of the Canadian provinces."

"Reports were received from all jurisdictions having financial responsibility laws execpt North Carolina, the District of Columbia, Hawaii (not interrogated), and Prince Edward Island.

${ }^{10}$ Most of the administrators who commented on the law stated simply that it was working "satisfactorily." In many cases, the comment was made by some subordinate official. In practically every case, the comment when elaborated, was a repetition, often verbatim, of the main arguments published by organizations sponsoring the various bills. Many letters contained suggestions for amendment. $A$ more detailed analysis of the administrators' reports may be found later in this study.

11 Twenty-one state bar associations replied to an inquiry as to what action, if any, had been talien on the general subject of automobile accident compensation. . Fourtcen reported no action. Iowa reported no definite stand had been taken. The New York report was innocuous. A North Dakota committce report favoring compulsory insurance was refused approval by the bar association. The reports from California, Ohio, Pennsylvania and Wisconsin were the only ones containing real discussions of the problem. The California report of August 6, 1934, shows no definite stand taken. The Ohio report of January, 1935, states that compulsory insurance and compensation schemes were disapproved in com- 
The information thus obtained has been tabulated and analyzed and is herewith presented. However, no attempt will be made herein to analyze the provisions of the various financial responsibility laws, a task undertaken elsewhere in this symposium. ${ }^{14}$ In order that the reader of this article may have before him the provisions of a typical law, the provisions of the A. A. A. bill will be briefly sketched.

The present financial responsibility laws of sixteen American jurisdictions ${ }^{\mathbf{1 5}}$ arc modeled after this bill or one of its revisions, all of which concern both criminal convictions and civil judgments. The I935 revision does not specify the convictions upon which proof of financial responsibility may be required, but incorporates the offenses which justify suspension or revocation of license or registration under the existing law of the adopting state, including offenses in any other state which if committed in the adopting state would require suspension or revocation. Such suspension or revocation in the case of a resident, or loss of road privileges within the state in case of a non-resident, may be terminated on the filing of proof of financial responsibility for future accidents, in the form of an insurance certificate, surety bond, or deposit of cash or securities, in the amount of \$5,000 and \$10,000 for personal injuries or death and $\$ x, 000$ for property damage. Either an operator's or owner's policy or both may be required. In addition to proof on conviction, the bill provides that judgments in any amount for personal injury or property damage rendered in any court in the United States or Canada must be paid within thirty days, on penalty of suspension or revocation, or loss of road privileges, until the judgment is paid (or payment by instalments provided for) and proof furnished. A certified copy of the judgment or order must be sent by the court or clerk to the commissioner. Proof may be waived or cancelled after the lapse of three years.

mittee because of legislative obstacles, and indorses financial responsibility laws. The majority of a special committee of the Pennsylvania Bar Association on automobile accident compensation reported in I935 in favor of compulsory insurance. The Wisconsin Bar Association, at its 1934 meeting, voted informally in favor of compulsory insurance. On the whole, the bar association reports show a lack of information or interest on the part of the profession, and a sharp divergence of opinion where action has been taken.

${ }^{22}$ Some of the most informative articles on the subject, legal and non-legal, are the following: INTERIM Report on Compulsory Insurance and Safety Responsibility Laws, by the [Ontario] Royal Comaission on 'Automobile Insurance Premium Rates (1930); 30 Col. L. Rev. I09 (1930); Report by the Committee to Study Compensation for Automobile Accidents to the Columbla University Council for Research in the Social Sciences (1932) (hereafter cited as tue Columbia Report); Report of Secretarx [California] Commitee on Administration of Justice (1934); Feinsinget, Financial Responsibility Laws and Compulsory Insurance: The Problem in Wisconsin (I935) 10 Wis. L. REv. 192; Report of Special Committee on Automobile Accident Compensation to the Pennsylvania Bar Association (1935) (hereafter cited as the Pennsylvania Bar Report).

${ }^{13}$ Decisions on particular problems will be referred to at appropriate points in the study. At this point, mention might be made of decisions and comments on the constitutionality of typical or particular financial responsibility laws: Ex parte Lindley, Io8 Cal. App. 258, 291 Pac. 638 (1930), overruled by Watson v. Division of Motor Vehicles, 212 Cal. 279, 298 Pac. 48I (I93I); Note (1930) I6 CoRN. L. Q. 229; (I93I) 4 So. Calif. L. Rev. 409; See Opinion of the Justices, 251 Mass. 569 , I47 N. E. 680 (1925); Opinion of the Justices, $8 \mathrm{r}$ N. H. 566, r29 Atl. II7 (1925).

"Sce Braun, The Financial Responsibility Law, supra p. 505.

${ }^{15}$ Arizona, California, Colorado, District of Columbia, Delaware, Indiana, Kentucky, Maryland, Michigan, Ncbraska, New Jersey, New York, North Carolina, Oregon, West Virginia, and Wisconsin. 


\section{Theory and Administration}

A fair appraisal of the operation of any law requires an understanding of its objectives. As to financial responsibility laws, the ends of safety and compensation have been all too often confused in the minds of sponsors, critics, and administrators. ${ }^{10}$ As a safety measure, a law of this nature should be classified with such factors as better roads, improved cars, stricter license issuance, and closer traffic control. ${ }^{10 "}$ As a compensation measure, it should be compared with compulsory insurance and compensation plans. In both respects, the law depends for its effectiveness on the mechanism of suspension or revocation of driving license or ownership certificate. Broadly, a person shown to be a bad driver, may lose his driving or ownership privileges pending the furnishing of proof, or payment of damages, or both. Allowing for differences of opinion as to emphasis, the following may be regarded as a composite list of the main objects of the law:
A. Segregating the bad driver.
B. Preventing or decreasing automobile accidents.
C. Compelling the known bad driver to insure.
D. Procuring payment of past damage.
E. Increasing the proportion of insured cars or drivers.

\section{A. Segregating the bad driver.}

The problem of segregating the bad driver might be attacked by an effective scheme of license issuance, accident reporting, and determination of fault followed by the imposition of proper penalties. Financial responsibility laws as such contribute nothing new in these respects, although they may be enacted concurrently with or as supplementary to other laws which are so designed. ${ }^{17}$ Proof of financial responsibility or payment of damages or both are usually required only in lieu of suspension or revocation, provisions for which were often previously in force and in some states now exist wholly without or operate independently of provisions for proof. ${ }^{18}$ It might be contended that inasmuch as the latter enhance the possibility of

${ }^{10}$ Observe, for example, the following statement in an official report in one of the states studied: "The New Jersey Financial Responsibility Law has two principal purposes. First-to promote security for payment of damages by motorists, where legally due, and second, to promote safety by removing from the roads those financially irresponsible motorists who have proved themselves to be reckless or unfit."

The word "safety" is often used in two senses: (I) the physical sense, referring to the effect of such laws in barring bad drivers from the road; (2) the pecuniary sense, referring to the effect of insuring compensation for injuries. The first is the more common meaning of the term, and the sense in which the word is used throughout this study.

${ }^{10 a}$ See Accident FAcrs (1936 ed.), published by National Safety Council, Inc., at 37, 38, for a discussion of accident causes.

${ }^{17}$ Drivers' license and accident reporting statutes are independent of financial responsibility laws and are designed for broader functions. The typical financial responsibility law relies on the old methods of fault finding, namely, conviction and judgment. Laws providing for determination of fault by an administrative official have been criticised as ineffectual. See Columbis Report, at 98-99. A third basis, -prior accident record--is growing in use.

${ }^{29}$ Act III (now Act II) of the Uniform Vehicle Code, known as the Uniform Motor Vehicle Operators' and Chauffeurs' License Act, was in force prior to financial responsibility laws. The Act contained as 
recovery, they provide an incentive to persons suffering damage to report accidents. But the extent to which this is true cannot be proved, ${ }^{19}$ and in any event, constitutes an incidental result rather than a main object or unique contribution of these laws. It is difficult to understand or substantiate the claims made for financial responsibility laws on the score of segregation.

\section{B. Preventing or decreasing automobile accidents.}

Much of the same criticism can be made of the claim that financial responsibility laws as such diminish the number of automobile accidents. The basis for the claim is the alleged number of bad drivers who are barred from the road through the operation of such laws. As the argument goes, the fewer bad drivers on the road, the fewer accidents. This may be conceded, and undoubtedly the process of suspension or revocation tends to that end. Unfortunately, however, the accident rate in the various states seems to bear little or no relation to the number of revocations or suspensions, ${ }^{20}$ indicating that other factors have greater significance. Nor does the process of suspension or revocation actually remove as many bad drivers, in absolute numbers, as might be assumed. ${ }^{21}$ But in any event, the question is not whether the scheme of suspension or revocation decreases accidents but whether financial responsibility laws as such have that effect, keeping in mind the fact that suspension or revocation laws antedated and exist independently of financial responsibility laws. ${ }^{22}$ The answer is quite disturbing, for if a driver threatened with suspension or revocation can furnish proof or pay previous damage or both, in

one of its principal features a provision for temporary or permanent suspension or revocation for certain traffic offenses. See the undated publication entitled Uniform Traffic Laws, published by the National Conference on Street and Highway Safety, at pp. 18, 22. Such provisions were enacted prior to financial responsibility laws in many states now having the latter law, and exist in about ten states not yet having such a law. The revised A.A.A. bill adds no new offenses but simply incorporates the previously existing grounds for suspension or revocation in any particular state. To illustrate the extent to which provisions for suspension or revocation might operate independently of proof, in the same state, refcrence may be made to N. Y. Legis. Doc. No. II (1936) Table No. 8, pp. 42-43, showing that in 1935, of 249,281 revocations and suspensions, only 61,787 or about 25 per cent were cases requiring proof of financial responsibility. In Pennsylvania during 1935 the Division of Safety of the Department of Revenue held 12,699 hearings, resulting in suspension in 49.9 per cent of the cases, while requiring proof in only 6.6 per cent. Financial responsibility laws may perhaps perfect the scheme of suspension or revocation and do usually add judgments thereto, but the procedure of suspension, or revocation as a segregation or safety measure could proceed as well if not better without the requirement of proof: for example, by tying it up with drivers' tests instead of with judgments or convictions.

${ }^{10}$ It is not to be expected that many persons injured will report or pursue an insolvent and uninsured wrongdoer merely that the latter will insure against future damage. As to solvent or insured persons, the law may actually discourage reporting by providing an incentive to settlement in order to save the wrongdoer the embarrassment of conviction or judgment and thereby an accident record, as well as the furnishing of proof.

${ }^{20}$ See Columbia Report, 103-r08; Pennsylvania Bar Report, 5-6. Later statistics support the statement in the text. In Vermont, for example, the percentage of registered cars involved in accidents from 193x through 1935 is as follows: 17, 20.I, 21.I, 19.3, I9.3. See Accident Facts, supra note 163, 2t 24-27, 44-45, 267-279, for accident and death data.

"see discussion, infra.

${ }^{22}$ See note 18, supra. 
most cases he is still permitted to drive. ${ }^{23}$ In other words, to the very extent that the law is effective in obtaining proof or payment it fails to remove bad drivers from the road and thus fails to prevent accidents. ${ }^{24}$ Therefore financial responsibility laws cannot properly be described as "safety" measures, in the sense of promoting physical safety, except as any measure penalizing bad driving which becomes known to the public can be so described. On the contrary they might be regarded as detrimental to the public safety by creating the illusion of safety and thereby preventing the enactment of more effective laws for controlling the bad driver.

\section{Compelling the known bad driver to insure.}

The requirement of proof of ability to compensate for future accidents following conviction or judgment in certain cases, in lieu of suspension or revocation, is the characteristic feature of financial responsibility laws. ${ }^{25}$ Such proof usually takes the form of a certificate of insurance. ${ }^{26}$ Granting that the threat of suspension or revocation causes some bad drivers to insure, the two questions which present themselves are: (I) whether the law by its terms is designed to reach a broad enough group of drivers; (2) whether the law as administered actually reaches those whom it was designed to affect. ${ }^{27}$

The proponents of financial responsibility laws do not claim that they affect all or a large percentage of drivers. On the contrary, they partially justify such laws in preference to compulsory insurance on the ground that the former do not operate on the majority of drivers, whom they assume to be careful.

${ }^{23}$ In a relatively few cases of extreme nature, the wrongdoer may be barred from the road despite his financial responsibility.

${ }^{2}$ Opponents of compulsory insurance have argued that it tends to increase accidents by inducing "a certain freedom of restraint from the consequences of rash driving." Sce PenNsylvania Bar Report (minority report) 15. If sound, this argument also applies to some extent to financial responsibility laws. See Columbia Report, at pp. 125-128. If it does apply, it tends to offset any gain by barring drivers who do not insure. However, as pointed out in the report, the argument is probably not based on fact. The statistics are not convincing. In Connecticut, the proportion of insured cars involved in accidents to all cars so involved has diminished steadily from 1930 , dropping from $73 \%$ in that year to $54 \%$ in 1935 . In the same state the percentage of all cars registered as well as of all drivers licensed involved in accidents has remained quite constant since 1931, with the 1935 figures less than those for 1934 but almost identical with those for 1933. The percentage of registered Maine cars involved in accidents causing personal injury has risen steadily since 1930, with a slight fluctuation in 1933-1934, the figures for 1934-1935 bẹing the highest of all.

${ }^{25}$ The requirement of payment of previous damage is of later origin, and does not strictly involve "financial responsibility" as the term was originally used. However, because of the close connection between proof and payment, the latter will be discussed.

${ }^{20}$ The number of cases in which other types of proof have been furnished is relatively insignificant. The alternatives are desirable, however, to give at least the appearance of flexibility.

${ }^{27}$ It has been found impossible to obtain data on the number of new policies certified as to proof after finding of fault, which is the only reliable test on this question. Mr. C. J. Haugh, Actuary for the National Bureau of Casualty and Surety Underwriters, has written that such' data are not available. 'The Columbia Report, at pp. 99, notes 5 and 6, indicates that the proportion of new to old policies so certificd is not large. In other words, many drivers compelled to furnish proof were previously insured and might have continued to insure regardless of the law. Of the remainder, some might have insured regardless of the law, following an accident, or conviction or judgment, as the realization of the necessity for insurance was brought home to them. 
To quote: 28

"The Safety-Responsibility Bill segregates and subjects to special regulations those, but only those, motorists who are convicted, in criminal or civil proceedings, of serious violations of the law or of having injured others. It does not affect motorists indiscriminately, nor penalize for trifling offenses, nor vex those involved in accidents which are the fault of others. Directed primarily at the menace to person and property from a reckless and criminal minority, the Safety-Responsibility Bill seeks to control this minority. The State is empowered to deprive of the use of the highways any operator who has demonstrated that he is an actual or potential menace to his fellow motorists and to the public in general, until he furnishes protection against damage caused by his future use of the highways." (Italics added.)

The use of the terms "reckless and criminal minority" and "actual or potential menace" tends to confuse the issue. In criticism of the first term, ordinary negligence may suffice for a conviction or judgment requiring proof; relatively few accidents are caused by "repeaters"; 29 and each year's crop of new license applicants must inevitably provide a new group of potential accident-causing drivers. ${ }^{30}$ In criticism of the second term, every driver is in a very real sense an "actual or potential menace." An automobile, regardless of legal theory, is a dangerous instrumentality; most drivers at some time or other "take a chance," including people who are reasonably prudent men otherwise; 31 finally, "careless" driving is a legal phenomenon, as to which a jury verdict, or the opinion of a judge or administrator, is neither predictable nor conclusive. Thus in one sense the law is broader than it should be, since it extends beyond a "reckless and criminal minority." In another sense it is not broad enough since it does not extend to every "actual or potential menace"; to cover every such case, it would have to include all drivers and cars.

How effective is the law in compelling those bad drivers within its scope to insure? The law is conditioned on the happening of an accident, which must be reported to the appropriate public official. Many accidents are not reported despite the occurrence of damage. Reporting depends mainly on private initiative, usually on action by the party injured. The latter may not report the accident if

\footnotetext{
${ }^{29}$ Introduction by Mr. S. Edward Gable, then Chairman, Safety-Responsibility Committee, American Automobile Association, to the I935 revision of the "Safety-Responsibility Bill."

${ }_{20}$ The Vermont accident figures for 1935 show the following: previous accidents, 2,106; no previous accidents, 4,422; not stated, 222 . In Rhode Island, of 4,508 operators involved in accidents, 3,635 had no previous accident record, and the records of ro3 were unknown.

${ }^{30}$ Of this group a certain percentage would have to be classified as "potential menaces" by any test, yet financial responsibility laws generally make no provision for their control, with the exception of the Uniform Automobile Liability Security Act which requires proof of all minors; the California law, Cal. Stat. 1935 , c. $27, \$ 350$, which as a prerequisite to a license, in absence of a parent's signature, requires proof of emancipated and non-resident minors; and the Connecticut act, which requires proof of minors between 16 and 18 applying for license, and, according to an administrative report, between 16 and 21 applying for registration. Conn. Gen. Srat. (Supp. 1937-r935) \$569c.

${ }_{31}$ The point is graphically illustrated in a pamphlet published for 1936 by the Travelers Insurance Company, Live and Let Live, at pp. 24, 25. As a further illustration, Rhode Island reports that of 4,508 drivers involved in accidents, 2829 had had five or more years driving experience. For many of the 4,508 , the accident in question was the first. See note 29 , supra.
} 
the other party has no assets or insurance, or if a settlement is made. ${ }^{32}$ After a report, there must be a finding of fault, usually by conviction or judgment. Again the necessary private pressure may be lacking because the plaintiff is aware that the defendant is judgment-proof, because he settles out of court, or for other reasons. In a study conducted on a small scale, it was found that over 90 per cent of claims filed with insurers and between 64 and 75 per cent of accident suits instituted, were settled out of court. ${ }^{33}$ Some idea of the small percentage of cases which actually result in judgment may thus be obtained. Moreover, many.judgments will not exceed the minimum amounts set by some statutes.

An alternative to the judgment-requirement, provision for a finding of fault by the commissioner or court, without reference to judgment, seems to have met with varied success. Connecticut has repealed its law, while in New Jersey, Vermont and New Hampshire such a law is still in effect. The Connecticut commissioner feels that the change from an accident to conviction basis has seriously affected the operation of its law; the statistics support him, and strengthen the assertion that the necessity of obtaining a formal conviction or judgment as a condition to requiring proof or payment is a serious defect in the usual law as a compensation measure. Connecticut and Pennsylvania provide for proof where a person is shown to have an accident record. Such a provision seems to have a greater administrative efficacy than one based entirely on fault in a particular accident. In 1934-1935, Pennsylvania required proof in 829 cases, because of an accident record. Connecticut has required proof in about 4,000 cases annually on a similar basis.

For a conviction to be effective to subject an operator to the requirement of proof, it must, of course, be for one of the offenses justifying revocation or suspension, a list varying too widely for enumeration but ranging from four or five to a dozen or more offenses. Moreover, the record of a conviction (or judgment) may never be filed with the motor vehicle commissioner. In most states there is no penalty on the court or the clerk for such a failure. ${ }^{34}$ But even where the conviction or judgment has been filed, it may be vacated or reversed, ${ }^{35}$ or proof may never be demanded by the administrator or, if demanded, may be refused. In Vermont, for instance, from I927 through $1935,15,38 \mathrm{I}$ persons were required to file. The records show 8,724 filed and 5,603 did not file, leaving a difference of 958 unaccounted for. Some of these were relieved from the requirement, but apparently others were lost in the

\footnotetext{
${ }^{32}$ It is impossible and useless to estiphate the proportion of reported accidents resulting in conviction, judgment, or other finding of fault, so numerous and varied are the reasons for the failure to prove or find fault. As to convictions, it is important to note that most prosecutions are under municipal traffic ordinances, while financial responsibility laws are limited to violations of state laws. Thus a great number of cases are at once removed from the operation of the law. See Feinsinger, supra note 12, at 202203. As to judgments, the minimum amounts, where they exist, are generally regarded as so high as to exclude a large number of cases which should be included.

${ }^{33}$ Feinsinger, supra note 12, at 219 .

${ }^{*}$ Some statutes, as in Wisconsin, release proof pending appeal or on judgment being vacated or reversed. In a state like Wisconsin which construes the statute as meaning vacated for any reason, the practice of vacating the judgment on settlement has become widespread. In such cases the state is deprived of a record of the judgment debtor and the public does not have the benefit of proof for future accidents. See id. at 203-206.
} 
shuffle, perhaps unlocated. In California from r93 to I935 inclusive, proof was filed in 839 , or less than 25 per cent, of the 3,432 cases of filed judgments. The percentage has been increasing gradually, however. In 1935 it exceeded 45 per cent. In Connecticut from 1926 to 1935 inclusive, proof has been required in I01,055 cases, and furnished in 58,124 or 57 per cent of the cases. The compliance figures during that period, in percentages, are as follows: $46,52,65,58,56,66,74,56,38$, and 36 . These figures indicate a growing disregard for the law since 1932. In Maine from July I, I 928 to July $x, 1935,7,642$ persons convicted were required to file, of whom $x, 992$ or 26 per cent complied. Of $\mathrm{x}, 769$ owners required to file in the same period, $x, 04 \mathrm{I}$ or 59 per cent complied. In 1935 in New Jersey, total revocations for non-compliance, including both conviction and judgment cases, were 7,Iro, with 2,916 restorations after establishing financial responsibility. In Pennsylvania during 1934-I935, 7 I2 operators were suspended for failure to file proof, nearly one-fifth the number who actually filed. In Vermont from 1927 to 1935 inclusive, proof was demanded in 14,327 cases, received in 8,724 or roughly 60 per cent and not furnished in 5,603 cases or roughly $4^{\circ}$ per cent. The percentage of compliance since $193^{2}$ is as follows: $661 / 2,56,501 / 2$, and 53 per cent.

Even where proof is given the risk of lapse or cancellation is serious. In I934I935 in Pennsylvania 360 operators were suspended for lapse of proof or failure or refusal to renew, while 1,842 actual renewals were received. In August 1936, 108 operators were suspended for lapse of proof, while $35^{6}$ renewals were received. In New Jersey in 1935, 3,ro5 cancellation notices were received from insurers. In New York, from I930 through $1935,6,947$ cancellations occurred. In Pennsylvania, I43 cancellations were received in 1934, 459 in 1935, and 74 in the month of August 1936. In the latter month there were 55 operators suspended for cancellation of proof. Several state administrators, particularly Indiana and West Virginia, complained of the hardship involved by reason of refusal of companies to insure drivers or cars after suspension or revocation, or cancellation of proof. West Virginia reports that of 3,000 drivers suspended only 50 could obtain insurance; as a result, one year's suspension is regarded as adequate under the law. This situation presents one of the most vital problems in both financial responsibility and compulsory insurance schemes.

When an operator has failed to file proof or where the proof filed has lapsed or has been cancelled, the law contemplates that his license or certificate or plates will be taken up and that steps will be taken to see that thereafter the operator stays off the road. Information as to the effectiveness of this enforcement is not comprehensive, but some figures have been obtained. In Connecticut driving privileges were revoked, from I928 to I935 inclusive, in 60 per cent of the cases where proof was required but not filed. In Vermont from 1927 to 1935 inclusive, revocation took place in 93 per cent of cases of non-compliance; the figure for 1935 was 92 per cent. In New Jersey in 1935 there were I,39I judgment cases; revocations occurred in I,222; 928 sets of plates were taken up. 
Since 193I in Connecticut 884 penalties have been imposed for driving while suspended. The figures annually are as follows: $162,140,197,207,207$. It is impossible to determine how many more suspended persons drove. From 1927-1935 inclusive, Vermont required proof of 260 persons for driving while suspended. It is impossible to tell whether the additional penalty kept these drivers off the road. It must be remembered that in most states in the usual case the requirement of proof is relieved after three years of filing. There are no statistics available to show how many accidents were caused by operators during or after the three year period.

The difficulties canvassed above have hampered the operation of the law as intended. Certainly some bad drivers insure who would otherwise not have done so, often because their business or other interests will not permit them to forego the use of their cars. ${ }^{38}$ For that reason, the law may be preferable to no such law. But the number who insure because of this law is nothing like that hoped for. Even where complete statistics are unavailable, one's immediate reaction is that the law is not relatively very effective. In California, for example, since I93I, proof has been filed in only 2,327 cases, the total for I935 being 952 . In Wisconsin, since 1931, proof has been filed in only 942 cases. And in Pennsylvania, since 1934, the total number of new policies has raised the proportion of Pennsylvania cars insured less than one per cent. ${ }^{37}$ Of 5,430 persons filing proof from January I, I934 to September, I936, excluding January, I936, I,667 had former insurance; 2,169 had not; 1,920 did not state. The figures on insurance elsewhere are not satisfactory and the necessary information seems unobtainable. The Vermont report shows that from I93I through 1935 insured cars or operators involved in accidents were as follows: 5,221, 4,163, $3,524,4,034,4,165$. However, no comparative data are given, except for 1935 , in which year cars or operators insured totalled 4,165; not insured 2,344; and not stated, 24x.

It may very well be felt that by lulling the public into a false sense of security, thereby lessening the demand for more adequate legislation, financial responsibility laws are a hindrance rather than an aid in accomplishing the solution of the problem of compensation for automobile injuries by the device of insurance.

\section{Procuring the payment of past damage.}

The early financial responsibility laws made no provision for the payment of past damage, but required only proof of ability to respond in damages for future accidents. The widespread demand for change resulted in the so-called "damage judgment law," now in force in 23 jurisdictions, requiring the payment of past damage in lieu of suspension or revocation. Such a provision may exist independently of or in conjunction with the ordinary requirement as to proof. ${ }^{38}$ Like the latter it has no particular effect in segregating the bad driver or in decreasing accidents.

How effective is the damage judgment law in procuring the payment of past damage? To begin with it may be limited to judgments above a certain amount. ${ }^{30}$

\footnotetext{
${ }^{\infty}$ From 10-25 per cent of all cars engaged in accidents are commercial vehicles of one type or another.

${ }^{5}$ See Pennsyzvania Bar Report, at 4-5, stating that the majority of certificates relate to old policies.

${ }^{23}$ In $x_{7}$ states it exists concurrently with a requirement for proof. In six states it exists alone.

${ }^{\infty}$ In New Jersey, for example, the judgment must exceed \$100; in Pennsylvania, \$200.
} 
Next, while an injured party is encouraged to report the accident and proceed to judgment because the law benefits him and not merely the future victim, he may still feel unable or unwilling to take action, particularly where the wrongdoing party is insolvent and has no insurance. In addition, there are the same or similar administrative loopholes impairing the law's effectiveness in action, as discussed in connection with financial responsibility laws in general. These considerations are reflected in the statistics. Thus, in Maine, from July I, I930 to July I, I935, only II2 persons had their operating privileges suspended pending satisfaction of judgment. The statistics show no trend, the r 935 figure being third from high and fourth from low. In New Jersey, an official report for 1935 recites a total of I,39I judgment cases, 289 judgments satisfied and proof furnished. The New Jersey report states that the figures do not show the full value of the damage judgment law, since often a threat to report the debtor forces a settlement. It might be suggested that this is not an unmixed blessing, since it deprives the state of a record of the driver and prevents the requirement of proof for the payment of future damages. In some cases this may have vicious results, in that by settling a small judgment an irresponsible driver may continue to operate his car until he causes damage which he cannot pay. In New York, from I930 through I935 a total of 10,176 licenses were suspended or revoked for failure to satisfy judgment, the number for 1935 being second highest. Apparently in these cases either the fear of loss of driving privileges was not a sufficient incentive to payment, or the wrongdoer could not pay. In I934-1935 in Pennsylvania, 75 operators were suspended for failure to satisfy judgment. In August, 1936, the number was 13 .

The net result of the law's administration is much less favorable than intended. ${ }^{40}$ Of course, the law is new, dating from 1929 and widely adopted only in the last three years, and many of the loopholes can be plugged. ${ }^{41}$ But the characteristic which distinguishes it from compulsory insurance, namely, its operation contingent upon the obtaining of a judgment, will prevent it from ever becoming as effective as compulsory insurance in the guaranteeing of compensation for automobile injuries.

\section{E. Increasing the proportion of insured cars or drivers.}

Financial responsibility and damage judgment laws are sometimes supported as tending to increase liability insurance on all cars, whether covered by the act or not. If this is so, it is mainly because the publicity attendant on the law has made owners or drivers "insurance conscious." This same result would probably follow from advertising any law relating to liability for automobile accidents. In any event, it is not at all clear from the data obtained that insurance has increased in the states in question or that the increase, if any, has been due to this factor. ${ }^{42}$

${ }^{\circ}$ See Pennsyluania Bar Report, at 6.

${ }^{4 S e c}$ part III, infra.

"Sec Columbia Report, at 98-100; Pennsylvanta Bar Report, at 5. The Columbia figures were based on estimates by the National Bureau of Casualty and Surety Underwriters, which in a recent letter expressed doubt as to the assumptions on which its previous estimate was made and declined even to guess at the present proportion of insured cars, stating moreover that the necessary data were probably nowhere available. 
III. Opinions op Administrators

The New York report is the only one which frankly advocated compulsory insurance. Connecticut is studying the whole problem to correct the "unsatisfactory condition which everyone admits is present under the current financial responsibility law." "42" But the great majority of administrators were of the opinion that the present law is satisfactory both in theory and operation, and preferable to either compulsory insurance or a compensation scheme. Many who admitted weaknesses in the law's operation felt that slight changes in the law or more adequate machinery for enforcement would suffice for cure. ${ }^{43}$ In many instances specific changes in the existing law were proposed, but in most cases these changes would merely bring the law of the states concerned into line with the more modern standard revisions. While most suggested changes were in the direction of strengthening the law, a few tended to greater liberality for first offenders or for offenders who needed the use of their cars in their business.

\section{Concluston}

It is inaccurate and misleading to describe financial responsibility laws as safety measures in the sense of segregating the careless driver or diminishing the number of accidents. These are not the peculiar functions of such laws and any such effect they may have, while commendable, is incidental. Their true functions are to guarantee the ability of a selected group of drivers or owners to respond in damages for future accidents, or to secure the payment of past damage, or both. In these respects, such laws are in theory an advance over the status quo ante, and in actual practice they accomplish their objects to some extent. But they have by no means accomplished all that was hoped by their sponsors. Although they have caused some bad drivers to insure and have forced the payment of some judgments, they do not in terms apply to a broad enough group of drivers to fit their own underlying theory, nor do they reach in practice a large proportion of persons to whom they do apply in terms. These inadequacies may be due partly to lack of familiarity with the law on the part of administrators as well as the public, or to defects which experience or legislation may remedy. At their best, however, financial responsibility laws cannot possibly approach compulsory insurance in the fulfillment of the function of either payment or insurance. ${ }^{44}$ Whatever may be decided as to the relative merits of the two schemes on the whole, it is necessary for a fair comparison that not only the theoretical but the administrative efficacy of both be understood. It is hoped that the statistical material and comments presented herein will aid towards a clear understanding of the whole problem and the preparation of a sound legislative program.

we Quoted from letter received from Mr. John C. Blackall, Secretary, Connecticut Commission to Study Financial Responsibility Act, dated Scpt. 28, 1936.

"See the minority argument, Pennsylvania Bar Report, at 17. See also "Compulsory Automobile Insurance," a published address by Mr. Joseph J. McGrath, Chief of the Rating Burcau of the Insurance Department of the State of New York, May 29, 1936. Mr. McGrath concedes the failure of the New York Financial Responsibility Act, adopted in $\mathrm{I929}$, as an alternative to compulsory insurance, but belicves it can be amended and enforced to serve its purpose.

"Granted the existence of administrative loopholes in the Massachusetts law, they exist mainly after insurance has been secured as a condition of obtaining a license, whereas under financial responsibility laws they occur before insurance is secured and may prevent that event from ever happening. This seems an all-important distinction. 